\title{
Variability studies among some okra (Abelmoschus esculentus LMoench.) accessions from Niger State, Nigeria
}

\author{
Mohammed A. K. ${ }^{1}$, Oladiran J.A. ${ }^{2}$, Gana A.S. ${ }^{2}$, Bashir M. ${ }^{1}$ \\ ${ }^{1}$ National Cereals Research Institute Badeggi, Niger State, Nigeria. \\ ${ }^{2}$ Federal University of Technology, Minna, Niger State, Nigeria.
}

\begin{abstract}
How to cite this paper: Mohammed A. K., Oladiran J.A., Gana A.S., Bashir M. (2020) Variability studies among some okra (Abelmoschus esculentus LMoench.) accessions from Niger State, Nigeria. International Journal of Food Science and Agriculture, 4(2), 143-147.

DOI: $10.26855 /$ ijfsa.2020.06.005
\end{abstract}

Received: March 12, 2020

Accepted: April 2, 2020

Published: April 13, 2020

*Corresponding author: Mohammed A. K., National Cereals Research Institute Badeggi, Niger State, Nigeria

Email: abu_sadeeq92@yahoo.com

\begin{abstract}
Field experiment was carried out at National Cereals Research Institute (NCRI), Badeggi research field, Niger State, to reveal the variability among some okra accessions. Thirty one accessions of okra were collected from farmers field and two (LD-88 and Nhae-47) collected from the department of crop production, Federal University of Technology Minna. The accessions were planted in Randomized Complete Block Design (RCBD) with three replications in a plot size of $2 \mathrm{~m} \times 1.5 \mathrm{~m}$. The experiment was carried out during dry and raining (2014/2015) season. Data were collected on twenty agro-morpholocal traits. Results of the principal component analysis (table 1 and table 2) of the combined seasons for the traits studied showed that the first five principal components accounts for $77.2 \%$ and $89.0 \%$ of the total variations in the population. Single Linkage Cluster Analysis (SLCA) display the accessions in accordance to their similarities level through the aid of dendrogram. SLCA of the combined season showed two major cluster groups that were linked at $65.7 \%$ level of similarity. Accessions that showed variability and clustered in different group may be useful for improvement of okra.
\end{abstract}

\section{Keywords}

Accessions, Variability, Clusters and Dendrogram

\section{Introduction}

Okra is a member of the family Malvaceae and genus Abelmoschus. Okra has a prominent position among fruit vegetables due to its multiple virtues like high nutritive and medicinal value, ease of cultivation, wide adaptability, year round cultivation, good portability, export potential and bountiful returns [1]. It is a multipurpose crop due to the numerous uses of the fresh leaves, buds, flowers, pods and stems, dry stems, pods and seeds [2,3]. Nigeria is the second largest producer of okra in the world (1,978,286 t) followed by Sudan and Mali [4]. However, yield in Nigeria is 2.86 tha $^{-1}$ compared with $24.70,20.60,13.20,9.98$, and 3.58 tha $^{-1}$ in Senegal, Ghana, Egypt, Kenya and Benin Republic respectively [5].

A total of 2,283 okra accessions had been reported world-wide [6]. A total of $77.49 \%$ of the okra accessions are currently found in West Africa [7]. It has been reported [8] that Okra varieties vary in plant height, size of fruit, colour, early or late maturing, long pod, lady finger, dwarf green pods. [9] also reported variability in characters such as yield, plant height, pod length, pod diameter, pod colour and number of days to flowering of okra. 
Measuring of genetic diversity and determining the variation between accessions helps ensure germplasm is efficiently collected and managed. The success of breeding program depends to a large measure on the degree of genetic divergence and genetic diversity which is a key factor for crop improvement [1].

Plant breeders can use genetic similarity information to complement phenotypic information in the development of breeding populations [10]. Variation is an important attribute in breeding programs [11]. [12] reported that the success of a crop improvement programs are highly reliant on the efficient manipulation of genetic variability. The yield of okra obtained per unit area in Nigeria is very low which need to be improved upon and revealing the variability among the diverse accessions will aid the breeders evolve new genotypes that will be high yielding, disease and pest resistant. Therefore this study was conducted to collect, evaluate and revealed the variation that exists among some okra accession.

\section{Materials And Methods}

Fruits of 31 accessions of okra were collected from Bosso, Paiko, Shiroro, Bida, Lavun, Mashegu, Katcha and Mokwa Local Government Areas of Niger state, Nigeria. NHe-47-1 and LD-88-1 Okra varieties, which serve as standard checks were obtained from the department of crop production, Federal University of Technology Minna, Nigeria.

Field evaluation studies were conducted in two growing seasons: under irrigation in 2014 dry season and 2015

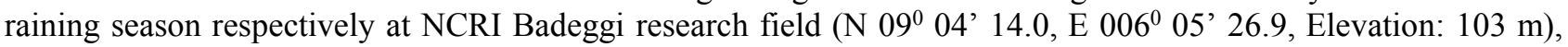
Niger State, Nigeria. The 33 accessions were planted in a randomized complete block design (RCBD) in three replications with a plot size of $2 \mathrm{~m} \times 1.5 \mathrm{~m}$. Each row was $2 \mathrm{~m}$ long with inter row spacing of $75 \mathrm{~cm}$. The spacing between plants along a row was $50 \mathrm{~cm}(75 \mathrm{~cm} \times 50 \mathrm{~cm}$ spacing) giving five stands per row. The plants were thinned to two per stand at two weeks after seed sowing. NPK 15:15:15 fertilizer was applied at the rate of $200 \mathrm{~kg}$ per hectare after three weeks of planting. Manual hand weeding was carryout (using hoe) twice at 3 and 8 weeks after sowing (WAS). Five plants were selected from each row for data collection on leaf colour, leave shape, fruit shape, position of fruits on main stem, fruit hairiness and petiole colour. A standard crop descriptor for okra [13] was used to measure the various parameters. The data collected were used for Principal Component Analysis (PCA) and Cluster analysis to determine genetic variation and percentage similarities using Statistical Tool for Agricultural Research (STAR, 2013).

Table 1: Physio-chemical properties of the soil (experimental site)

$\begin{array}{cc}\text { Sand (\%) } & 91.52 \\ \text { Silt (\%) } & 3.28 \\ \text { Clay (\%) } & 5.20 \\ \text { pH } & 6.12 \\ \text { Organic Carbon (\%) } & 0.88 \\ \text { Organic Matter (\%) } & 1.51 \\ \text { Total N (\%) } & 0.13 \\ \left.\text { Available P (cmol kg }{ }^{-1}\right) & 14.0\end{array}$

\section{Results}

\subsection{Combined Seasons Principal Component Analysis of Quantitative traits}

The result of the combined analysis presented in Table 2 revealed that, PC1 accounted for $25.7 \%$ of the total variation. The only character that made negative contribution to variation by PC1 was $100-\mathrm{SW}(0.07)$. Principal component two, contain $18.2 \%$ of the total variation and characters that contributed more to variation includes fruit weight (0.42), fruit per plant (0.35) and fruit length (0.28). The third principal component account for $14.2 \%$ of the total variation and the seven characters that made negative contribution to variation by PC3 included petiole length (-0.35), FruitR (-0.33), Plant hgt (-0.27), NS/F (-0.17), SD (-0.08), 100SW (-0.05) and fruit R (-0.33). Principal component four made $10.8 \%$ contribution to total variation in this population and plant height $(0.37)$ 
contributed more to variation in this PC than other traits.

Table 2: Eigen value, Factor scores and contribution of the first five axes to variation in okra accessions of the combined season.

\begin{tabular}{|c|c|c|c|c|c|}
\hline Parameter & $\mathrm{PC} 1$ & PC2 & PC3 & PC4 & PC5 \\
\hline Plant hgt & 0.226 & 0.107 & -0.279 & 0.379 & -0.254 \\
\hline Petiole $\operatorname{lnt}$ & 0.283 & 0.265 & -0.358 & 0.284 & 0.271 \\
\hline $\mathrm{SD}$ & 0.402 & 0.144 & -0.081 & 0.093 & 0.396 \\
\hline No. of Node & 0.328 & -0.141 & 0.372 & -0.146 & -0.031 \\
\hline DTFFA & 0.290 & -0.474 & 0.198 & 0.076 & -0.107 \\
\hline $50 \%$ FLW & 0.280 & -0.497 & 0.098 & 0.130 & -0.111 \\
\hline FRUIT/P & 0.116 & 0.351 & 0.558 & 0.079 & -0.115 \\
\hline FRUITL & 0.020 & 0.288 & 0.005 & 0.026 & -0.536 \\
\hline FRUITR & 0.257 & 0.013 & -0.339 & -0.495 & -0.137 \\
\hline FRUITG & 0.444 & -0.038 & -0.034 & -0.133 & 0.238 \\
\hline FRUITW & 0.215 & 0.428 & 0.374 & -0.119 & 0.131 \\
\hline NS/P & 0.329 & 0.125 & -0.174 & -0.185 & -0.516 \\
\hline $100 \mathrm{SW}$ & -0.077 & 0.013 & -0.059 & -0.637 & 0.145 \\
\hline Eigen value & 3.3388 & 2.3660 & 1.8402 & 1.3993 & 1.0860 \\
\hline Percentage & 25.7 & 18.2 & 14.2 & 10.8 & 8.4 \\
\hline Cumulative & 25.7 & 43.9 & 58.0 & 68.8 & 77.2 \\
\hline
\end{tabular}

Plant hgt= plant height, Petiole lnt = Petiole length, $\mathrm{SD}=$ Stem diameter, No. of node = number of nodes/plant, $\mathrm{DTFFA}=\mathrm{days}$ to first flower appearance, $50 \% \mathrm{FLW}=$ days to $50 \%$ flowering, FRUIT $/ \mathrm{P}=$ Fruit per plant, FRUITL $=$ Fruit length, $\mathrm{FRUITG}=\mathrm{Fruit}$ girth, FRUITW/P= fruit weight per plot, NS/F= Seed per fruit, $100 \mathrm{SW}=100$ seed weight

\subsection{Principal Component Analysis of Qualitative Traits of Okra Accession Studied}

The first five principal components accounted for $89.0 \%$ of the total variations in this population. Leave shape (0.32) was the only character that positively contributed to the variation in PC1 (Table 3). A total of 33.9\% of the total variations in this population was derived from PC1, while PC2 accounts for $21.1 \%$ of total variations in the population. Fruit shape $(0.61)$, fruit position $(0.36)$ and stem colour $(0.17)$ were characters that contributed to variation by PC2. PC3 contained $13.5 \%$ of the total variations in the population and the traits, stem colour $(-0.33)$, fruit shape (-0.29), fruit hairiness (0.49) had negative contribution to variation in PC3. PC4 was responsible for $11.2 \%$ of total variations in the population, while only fruit hairiness $(0.46)$ and fruit position $(0.12)$ accounted for positive contribution of variation in PC4. PC5 contributed $9.0 \%$ of the total variations in the population; leave shape (0.62) contributed more to variation in PC5 than other characters.

Table 3: Eigen value, Factor scores and contribution of the first five axes to variation in okra accessions of the combined season (using qualitative characters)

\begin{tabular}{cccccc}
\hline Parameter & PC1 & PC2 & PC3 & PC4 & PC5 \\
\hline Leave colour & -0.503 & -0.327 & 0.153 & -0.065 & 0.183 \\
Stem colour & -0.387 & 0.176 & -0.337 & -0.689 & -0.207 \\
Fruit shape & -0.183 & 0.614 & -0.292 & -0.061 & 0.500 \\
Fruit Position & -0.279 & 0.368 & 0.672 & 0.123 & 0.305 \\
Fruit hairiness & -0.329 & -0.328 & -0.499 & 0.460 & 0.380 \\
Petiole colour & -0.523 & -0.273 & 0.243 & -0.090 & -0.214 \\
Leave shape & 0.323 & -0.410 & 0.136 & -0.532 & 0.624 \\
Eigen value & 2.372 & 1.477 & 0.944 & 0.782 & 0.654 \\
Percentage & 33.9 & 21.1 & 13.5 & 6.2 & 9.0 \\
Cumulative & 33.9 & 55.0 & 68.5 & 79.6 & 89.0 \\
\hline
\end{tabular}




\subsection{Cluster Analysis of Qualitative traits of Okra Accessions Studied}

Cluster analysis of the results of qualitative traits studied using complete linkage method revealed two major cluster groups (Figure 1). All accessions fell into one group except accession 16 and 31 that belonged to the second group. The two groups were linked at $65.7 \%$ level of similarity. The first major group was further divided into different sub groups depending on their level of similarities. Accessions 1 and 28, 13 and 27, 14 and 19, 12 and 13 showed close similarity levels.

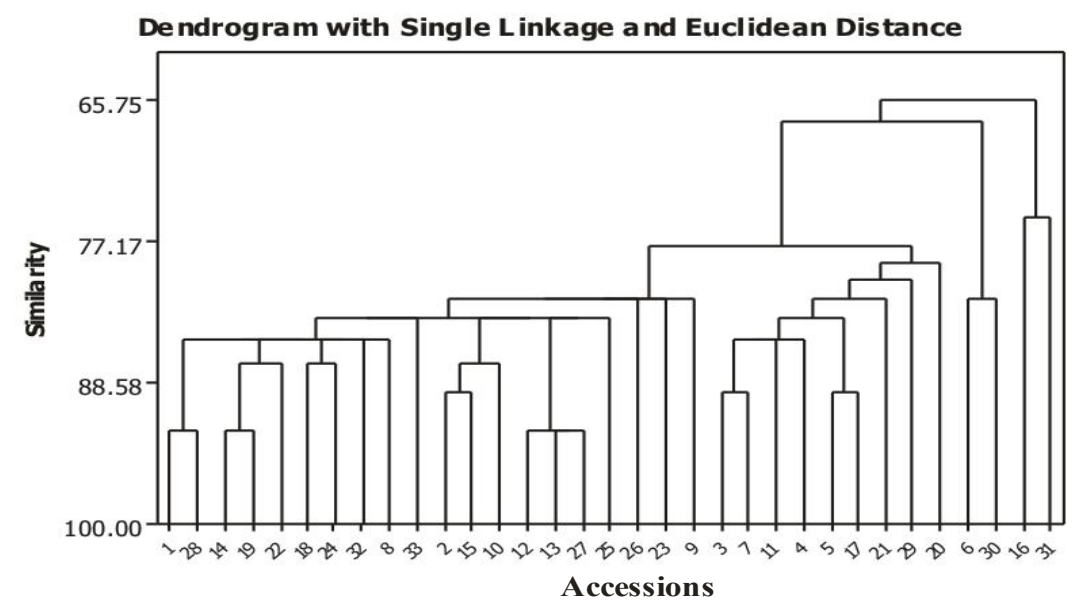

Figure 1. Dendrogram of the 33 Okra accessions based on qualitative traits result

Note that: Bata-01=1, Bata-02 $=02$, Dama-01=03, Dama $=04$, Egwa-01=05, Egwa-02 $=06$, Esungi $=07$, Gbadebo-01 $=08$, Gbadebo-02=09, Gbadebo-03=10, Gbadebo-04= 11, G-mayi= 12, Jazu= 13, K-Gar-01=14, K-Gar-02=15, K-Gar-03=16, Kwati= 17, LD-88 $=18$, NHae-47 $=19$, Pati- $01=20$, Pati- $02=21$, Pati- $03=22$, Pati- $04=23$, Pati- $05=24$, Pati $-06=25$, Shaba-01 $=26$, Shaba- $02=$ $27, \mathrm{~S}-\mathrm{Lambu}=28, \mathrm{~S}-\mathrm{Rami}=29, \mathrm{Tafita}=30$, Tafita $\mathrm{sss}=31, \mathrm{~T}-\mathrm{Daga}-01=32, \mathrm{~T}-\mathrm{Daga}-02=33$.

\section{Discussion}

The Qualitative parameters in this study had revealed variations among the accessions. Variability was noted in all the traits among the accessions studied. This result is in conformity with the result of a study conducted in Ghana [14], which showed significant difference in vegetative and reproductive traits of some okra cultivars which the authors stated that the phenotypic variation observed within the qualitative traits correspond to the diverse collection sites. It has been stated that genetic affinity between accessions from different regions could be attributed to selection and exchange of germplasm between farmers and ethnic groups [15]. Variability recorded in this study also agrees with the findings of [16], who reported high variability among fifty three okra accessions studied in Nigeria which might be due to genetic drift and selection in different environment.

The principal component analysis revealed the percentage contribution made by each character studied to the total variation in the population. Result of this work has revealed that different traits contributed differently to the total variation in the population which conform with the result obtained from the study carried out in Nigeria [17], using PCA to study variation among 29 okra accessions at Abeokuta, Nigeria. Characters that had high variability are expected to provide high level of gene transfer during breeding program as stated [18]. It has also been reported that, traits which associated with $\mathrm{PC} 1$ and PC2 are implicated for being responsible for the phenotypic divergence observed in the studied cultivars and can be used for cultivar discrimination [17].

The dendrogram obtained from Single Linkage Cluster Analysis (SLCA) of this study showed the accessions in accordance to their similarity percentage levels which revealed that, the accessions differed. [17] reported that, dendrogram drawn from SLCA showed the relationship accessions and stated that, SLCA provided information on the minimum percentage similarity among accessions and also provided an overall pattern of variations as well as degree of relatedness among accessions. However the accessions used in this study might have originated from parents with diverse genetic background since their genetic similarity index is lower than $95 \%$, because it has been documented that, for any two or more accessions to be taken as genetically identical, their genetic similarity index (GSI) should be equal to or greater than 95\% [19]. 


\section{Conclusion}

Variations existed among the okra accessions used in this studied. PCA and SLCA revealed contributions and distinctiveness of traits among the accessions. Existence of variations in the population revealed that the genotypes had different genetic make-up which can be utilized for okra improvement. The dendrogram showed distinctiveness and relatedness among the accessions depending on their characteristics. Accessions that cluster in different groups with higher variability (lower similarity percentage) should be used for okra improvements.

\section{References}

[1] Reddy, M. T., Haribabu, K., Ganesh, M., Reddy, C. K., \& Begum, H. (2012). Genetic divergence analysis of indigenous and exotic collections of okra (Abelmoschus esculentus (L.) Moench). Journal of Agricultural Technology, 8(2), 611-623.

[2] Schippers, R. R. (2000). African indigenous vegetable an overview of the cultivated species. National Resources Institute (NRI), University of Greenwich, London, united Kingdom, 214.

[3] Siemonsma, J. S., \& Kouame, C. (2004). Abelmoschus esculentus (L.) Moench. Internet Record from Protabase. Grubben GJH, Denton OA (eds.), PROTA (Plant Resources of Tropical Africa, Wageningen, Netherlands. http://database.prota.org/search.htm

[4] FAOSTAT, (2016). Food and Agricultural Organization of the United Nations. www.factfish.com/statistic/okra\%2c\%20yield

[5] FAOSTAT, (2013). Statistical Database of the Food and Agriculture of the United Nations. Available from: http://faostat.fao.org/beta/en/\#data/QC

[6] Anonymous (2006). Lost Crops of Africa Volume II: Vegetables. National Academies Press. www.nap.edu/catalog/11763.html, 287-301.

[7] Oppong-Sekyere, D., Akromah, R., Nyamah, E. Y., Brenya, E., \& Yeboah, S. (2011). Characterization of okra (Abelmoschus spp. L.) germplasm based on morphological characters in Ghana. Journal of Plant Breeding and Crop science, 3(13), $367-378$.

[8] Udoh, D. J., Ndon, B. A., Asuquo, P. E., \& Ndaeyo, N. U. (2005): Crop Production Techniques for the Tropics, 223 - 247.

[9] Abdelmajeed, A., Faridah, Q., \& El Hassan, G. (2012). Inheritance studies of some pod traits in Okra (Abelmoschus esculentus (L) Moench). Journal of Medicinal Plants Research, 6(49), 5905-5911.

[10] Yuzbasioglu, E., Ozcan, S., \& Acik, L. (2006). Analysis of genetic relationships among Turkish cultivars and breeding lines of Lens culinatis Mestile using RAPD markers. Genetics Resources and Crop Science, 53, 507-514.

[11] Monhinmin, C. A., \& Osawaru, M. E. (2005). Morphological characterization of two species of Abelmoschus esculentus and A. caillei. Plant Genetic Resources Newsletter 144, 51-55.

[12] Gana, A. S., Shaba, S. Z., \& Tsado, E. K. (2013). Principal component analysis of morphological traits in thirty-nine accessions of rice (Oryza sativa L.) grown in a rainfed lowland ecology of Nigeria. Journal of Plant Breeding and Crop science. 5(x), $120-126$.

[13] IBPGR (1991). Report of international workshop on okra genetic resources. National Bureau for Plant Genetic Resources (NBPGR), New Delhi, India.

[14] Amoatcy, H. M., Ahiakpa, J. K., Quartey, E. K., Segbefia, M. M., Doku, H. A., Sossah, F. L., \& Klu, G. Y. P. (2015). Agromorphological characterization of 29 accessions of okra (Abelmoschus spp L.). Journal of Biology, Agriculture and Healthcare, 5, 2224-3208.

[15] Oppong-Sekyere, D., Akromah, R., Nyamah, E. Y., Brenya, E., \& Yeboah, S. (2011). Characterization of okra (Abelmoschus spp. L.) germplasm based on morphological characters in Ghana. Journal of Plant Breeding and Crop science, 3(13), $367-378$.

[16] Osawaru M.E., Ogwu M.C. and Dania-Ogbe F.M. (2013). Morphological assessment of the genetic variability among 53 accessions of west African okra (Abelmoschus caillei (A. Chev.) Stevels) from south western Nigeria. Nigeria Journal of Basic and Applied Science, 21(13): 227-238

[17] Nwangburuka, C. C., Kehinde, O. B., Ojo, D. K., Denton, O. A., \& Popoola, A. R. (2011). Morphological classification of genetic diversity in cultivated okra (Abelmoschus esculentus L. Moench) using principal component analysis (PCA) and single linkage cluster analysis (SLCA). African Journal of Biotechnology, 10(54), 11165-11172.

[18] Gana, A. S. (2006). Variability studies of the response of rice varieties to biotic and abiotic stress. Unpublished Ph.d Thesis, University of Illorin.

[19] Anderson, M. S., Schultze-Kraft, R., Peters, M., Duque, M.C., \& Gallego, G. (2007). Extent and structure of genetic diversity in a collection of the tropical multipurpose shrub legume Cratylia argentea Desv. O. Kuntae as revealed by RAPD maekers. Electronic Journal of Biotechnology, 10(3), 1-9. 